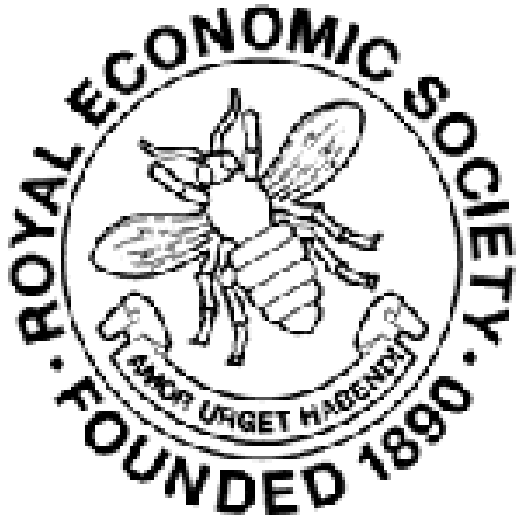

The Work of Women in France

Author(s): C. Osborn

Source: The Economic Journal, Vol. 13, No. 49 (Mar., 1903), pp. 131-133

Published by: Wiley on behalf of the Royal Economic Society

Stable URL: http://www.jstor.org/stable/2956884

Accessed: 27-06-2016 02:55 UTC

Your use of the JSTOR archive indicates your acceptance of the Terms \& Conditions of Use, available at

http://about.jstor.org/terms

JSTOR is a not-for-profit service that helps scholars, researchers, and students discover, use, and build upon a wide range of content in a trusted digital archive. We use information technology and tools to increase productivity and facilitate new forms of scholarship. For more information about JSTOR, please contact support@jstor.org.

Royal Economic Society, Wiley are collaborating with JSTOR to digitize, preserve and extend access to The Economic Journal 
flower-making; where with an excellent teacher, a generous equipment, the trade shall be taught in all its branches as an art as well as a trade; and where it can be tested whether, given the ideal of producing good work for its own sake, of executing true and artistic representations of natural objects, the ambition and enthusiasm, which is so lacking in our work girls, cannot be aroused.

Is not this the sort of work for which technical education has been given to the nation, and which we may hope in time to see it compass?

G. M. OAKeshott

\section{The Work of Women in France}

The May number of Le Musée Social contains a monograph by Mdlle. Schirmacher on the work of women in France, giving detailed statistics as to the occupations in which they are engaged and the rate of wages they receive. In France, there is a disproportion between the sexes, the number of adult women exceeding the number of adult men by about 430,000 , so, as the writer remarks, marriage is not possible for all women. Out of a working population of $18,000,000,12,000,000$ are men and 6,000,000 women. This latter figure does not include married women who are working as wives, mothers, and housekeepers, who number more than 7,700,000. Agriculture and farming claim the largest number of women workers, more than 2,700,000, and industries and manufactures come next with $1,888,000$. Domestic service, the only occupation in which the number of women employed exceeds that of the men, accounts for 737,000, and commerce and trade for 571,000. In none of the other occupations do the women exceed 170,000.

After touching on the work of married women as wives and mothers, a work, so the writer remarks, too often remunerated in inverse proportion to the exertions made and the trouble endured, Mdlle. Schirmacher goes on to examine in detail the main groups of occupations open to women. Of those engaged in agriculture about 1,250,000 are entered as "femmes chefs," but whether all these are small proprietors it has been impossible so discover. As to wages, the rate ranges between $2.01 \mathrm{fr}$. per day in the Seine department to $90 \mathrm{fr}$. per day in Morbihan. The rate is always lower than the normal rate for a man, being generally a little more than a half and a little less than two-thirds. In manufactures and industry, out of 1,893,000 women, $1,135,000$ are employed in the clothing trades; 463,000 are employed in the textile industries ; in other industries, though women are never entirely absent, their numbers are small. Wages are generally low in the clothing and textile trades; outside Paris, the rate barely averages 2 fr... a day. The maximum wage paid to a woman is not half the maximum paid to a man. Further, in an interesting table, Mdlle. Schirmacher shows 
that in 49 departments women are paid less than 2 fr. a day, or less than the sum required to maintain efficiency, while even where the rate is higher, the struggle to make two ends meet must be very severe. The same dismal story of wages too low for efficiency is repeated in nearly all the other occupations, and, from the figures given, it is evident that women have in France, as in England, been but very slightly touched by the Trade-Union Movement. It appears that in 1900 the number of women belonging to unions was just 27,000, while the total number of unionists of both sexes was 492,000, and the total number of women workers was 829,000. While women constitute about a third of the industrial army, they only represent a nineteenth part of the members of unions.

The women engaged in the cigar and match-making trades are the best organised, a very small number remaining outside the unions. But the proportion of women in unions among those engaged in the clothing and textile trades, where feminine workers are very numerous, is exceedingly small. The difficulty of organising women workers is very great, as Mdlle. Schirmacher points out, owing to their scanty means, their lack of political and social education, and their domestic occupations, and this she considers an argument in favour of State intervention for the improvement of the conditions under which they labour. The "sweating system " prevails widely in the clothing trade, particularly. in Paris where there are more than 600,000 isolated women home-workers.

In the printing trade, in France as in England, the men have resisted the entrance of women as compositors, and have refused them admission to their unions; but in many other trades mixed unions have been established.

In trade, it is interesting to note that out of nearly 556,000 women employed, 165,574 are "femmes chefs." But it is a curious fact that in spite of the talent which Frenchwomen have frequently shown in managing businesses, yet employers do not, as a general rule, give the slightest encouragement to their women assistants to develop their powers in this direction. Women employees have generally no prospect of advancement: all the higher positions in shops are reserved to men, and there is not in Paris, and probably not in France, a single woman who is forewoman of a department, except in those for dressmaking and underlinen.

Turning to the women who have entered liberal professions, it appears there are 83 women doctors, 18 women dentists, and one oculist. About 90,000 women are in the government service. Of these about 14,000 are employed in the postal, telegraph, and telephone service; 50,000 are teachers. The occupation of hospital nursing, which has been so successfully organised in England, is still in' a very unsatisfactory condition in France, though an effort is being made to improve the training and conditions of work. In conclusion, Mdlle Schirmacher sums up the many disadvantages against which women have to struggle, the domestic cares they have to bear, often in addition 
to their professional work, and sarcastically remarks that, in spite of all this, women are still called the "sexe faible." $\quad$ C. OsBorN

\section{The Hand-working and Domestic Industries in Germany}

The principal article in the May Number of The United States Bulletin of Labour is a detailed account by Mr. Henry J. Harris, Ph.D., of the "Present condition of the Hand-working and Domestic Industries in Germany," based on several valuable statistical publications dealing with the subject, which have been issued in that country in recent years.

In Germany, as in many other countries, the narrowing of the sphere of the working man's activity, owing to the growth of the factory system and the specialisation of labour which it entails, has led to a desire to preserve and cultivate the system of household or shop production, which was formerly the prevailing type of industrial life. The investigations with which Dr. Harris deals have largely been undertaken with this end in view. The two questions to which his article endeavours to give an answer are first, to what extent the small system of industry still survives, and second, what is its power of competition with the rival system of production on a large scale. The consideration of the interesting moral questions involved, and of the possible effect of the two systems on the character of the worker, does not come within the scope of the article.

An important point to bear in mind, when studying industrial conditions in Germany, is the very late date at which that country attained complete freedom from the nld mediæval restraints. At the close of the Napoleonic period all production was practically in the hands of the handicraft or artisan class, organised in guilds; but with the restoration of peace and the consequent revival of industrial activity, there was a steady movement for the abolition of the guild restrictions, though it was not till the end of the sixties that complete industrial freedom was attained. A chief factor in the development of the factory system was the improvement in the means of communication, but the transition to the newer form of production has been so recent that many signs of the older methods are to be found in the factories themselves, while the small system of production still holds its own to a very remarkable degree.

By the term "hand-work production," is understood that type in which the producer himself is the possessor of the means of production, in which he produces for a definite market or known body of consumers, and in which there is but slight use of machinery. The term has been roughly used to include such small shops or establishments where not more than 5 persons are employed, while establishments where not more than 50 persons are employed are classed as small factories. 